\title{
Comparison of Nutritional and Anti-Nutritional Qualities of Grewia forbesii Hav. Ex Mast and Grewia bicolor Juss Fruits from Kitapilimwa Forest Reserve in Iringa District
}

\author{
Vendeline E. Tairo \\ Department of Biological Sciences, Mkwawa University College of Education, \\ University of Dar es Salaam, P. O. Box 2513, Iringa, Tanzania. \\ E-mail:vtairo72@gmail.com
}

Received 21 Jun 2021, Revised 24 Sep 2021, Accepted 25 Sep 2021, Published Oct 2021

DOI: https://dx.doi.org/10.4314/tjs.v47i4.9

\begin{abstract}
The Grewia forbesii and Grewia bicolor fruits were collected from Kitapilimwa Forest Reserve and were analysed for proximate, nutrients and anti-nutrients compositions. Results showed low moisture contents in G. forbesii and G. bicolor amounting to 14.14 and 13.98 percent, respectively. Crude fibre percent was slightly higher in G. bicolor (33.15\%) than G. forbesii $(31.95 \%)$. Lipid content was slightly higher in $G$. bicolor $(1.37 \%)$ compared to $G$. forbesii $(1.28 \%)$. The crude protein content of G. forbesii $(7.44 \%)$ was slightly higher than G. bicolor (7.00\%). Total carbohydrate content of G. forbesii $(68.9 \%)$ was higher than that of G. bicolor (70\%). Mineral analysis indicated substantial amounts of potassium $898 \mathrm{mg} / 100 \mathrm{~g}$ in G. forbesii and $879 \mathrm{mg} / 100 \mathrm{~g}$ in G. bicolor. Calcium content was high in G. forbesii and G. bicolor amounting to $453 \mathrm{mg} / 100 \mathrm{~g}$ and $582 \mathrm{mg} / 100 \mathrm{~g}$, respectively. Iron was high in both species (20.73$24.45 \mathrm{mg} / 100 \mathrm{~g})$. Manganese, copper and zinc were substantially low. The results revealed low levels of tannin $(<1.7 \%)$ and phylates $(<0.3 \%)$. The presence of substantial amounts of nutrients and low anti-nutrients revealed that the studied species may be potential sources of nutritional food.
\end{abstract}

Keywords: Proximate analysis, mineral nutrients, anti-nutritional qualities, Grewia species, Kitapilimwa Forest Reserve.

\section{Introduction}

One of the greatest challenges facing thousands of people in Iringa District is that almost half of the region is semi-arid land, in which agriculture upon which the livelihoods of the people depend is greatly affected by erratic and unreliable rainfall regime and extreme poverty (Njau 2005, Tairo et al. 2011). Declining agricultural productivity and consequently food security is a result of climatic changes, poverty, diseases, and rainfall-dependent agriculture in such a way that the increasing population pressure has compelled people to switch to the use of wild food plants to cope with the situation of low food security (FAO 2000, Feyssa et al. 2011). While every livelihood option is being taken to increase food production by conventional agricultural production, a lot of attention is currently being focused on the potential of exploiting the huge numbers of familiar plant resources existing in the wild environment (FAO 2010, Tairo 2011).

Although utilization of such wild plants has been sufficiently documented, there is still a formidable lack of reports on their chemical 
compositions. Edible food plants could be good sources of nutrients, and many have the potential of broadening the present narrow food base of the human population (Elhassan and Yagi 2010). In Iringa District, fruits from the Grewia genus were commonly used to supplement other food sources (Tairo 2011). The Grewia is a genus of flowering plant belonging to the family Malvaceae. The Grewia species that were most commonly used included Grewia forbesii Hav. ex Mast and Grewia bicolor Juss (Tairo 2011). These species are known as mkole or mkone in Swahili, and also known as mkole or mperemehe in Hehe language (Ruffo et al. 2002).

Grewia forbesii is a multi-stemmed shrub or tree up to $12 \mathrm{~m}$ high, leaves are broadly elliptic, flowers and fruits are shallowly 2-4 lobed or none-lobed. Grewia bicolor is also a multi-stemmed shrub with 7 to $14 \mathrm{~m}$ high (Heuzé et al. 2015). Their barks are dark grey, deeply fissured and scaly in older trees. The phylotax of the leaves are alternate and shapes can be either elliptic or lanceolate. According to the Heuzé et al. (2015) the leaves are wide and bicoloured in which the upper surface is uninteresting green, while the lower one is silvery white. Grewia forbesii Hav. ex Mast and Grewia bicolor Juss fruits are the common fruits consumed by the people when they are ripe. In the dryland of Iringa District, Grewia fruits are used to make drinks when soaked and sweetened. Fruits flour is used to prepare porridge and served for young and adult ones during the day. Elhassan and Yagi (2010) reported that Grewia drinks can be taken regularly by the lactating mothers to improve their health and lactating abilities. In addition, the Grewia fruits can be fermented and served as an alcoholic drink. Also, there is an increasing demand of the fruits from these species because they are used as sources of traditional cures against malaria and iron deficiency anaemia (Elhassan and Yagi 2010, Heuzé et al. 2015). Although the fruits of Grewia species have high nutritional and nutraceutical potentials, limited or no investigation has been carried out on exploitation and utilization of the fruits as prospective food sources (Heuzé et al. 2015). Therefore, this study aimed at determining potential chemical components (nutrients and nutraceuticals) from the fruits of the Grewia species that may help to provide a logical data to the profile of this plant frequently used in the area.

\section{Materials and Methods}

The study was carried out in the communities located around Kitapilimwa Forest Reserve in Iringa District, Iringa Region. The forest reserve is located between latitude $7^{\circ} 28^{\prime} 00^{\prime \prime} \mathrm{S}$ and longitude $35^{\circ} 43^{\prime} 0{ }^{\prime \prime} \mathrm{E}$ and $1,245 \mathrm{~m}$ above sea level. The temperature of the area ranges from 12 to $30{ }^{\circ} \mathrm{C}$ and annual precipitation less than $1000 \mathrm{~mm}$ (URT 2001). The important resources available in the forest include medicinal plants, fruits, dry fuel wood, wild vegetables animals such as birds and insects, honey and minerals. The village is situated $8 \mathrm{~km}$ from the junction of the IringaDodoma road, $40 \mathrm{~km}$ from Iringa.

The Grewia plants were identified in the field by botanist form Tanzania Tree Seeds Agency by comparing with herbarium specimens and then fruits of Grewia forbesii Hav. ex Mast and Grewia bicolor Juss were collected from Kitapilimwa Forest Reserve from April to June in 2020. For every species, fruits were collected in different locations in the forest reserve and pooled together and one kilogram of fruits for each species were washed with running water and then passed through distilled water to remove dirt and foreign materials and dried in the shade for four days and passed in hot air for three days. Finally, fruits were ground, sieved through mesh screen and stored in air tight containers for laboratory analysis.

The samples were analysed in triplicates for proximate analysis. The parameters analysed included moisture, total ash, crude protein, crude lipid, crude fibres and carbohydrates contents using standard methods as outlined by AOAC (2000). 
The minerals were determined after sample wet digestion with a mixture of nitric acid $\left(\mathrm{HNO}_{3}\right)$, perchloric acid $\left(\mathrm{HClO}_{4}\right)$ and sulphuric acid $\left(\mathrm{H}_{2} \mathrm{SO}_{4}\right)$ and calcium, potassium, copper, zinc and manganese were determined by using atomic absorption spectrophotometer (AOAC 2000) in the laboratory of Food Technology, Nutrition and Consumer Sciences at Sokoine University of Agriculture. Anti-nutritional agents such as tannins and phylates were determined as described by Singleton et al. (1999) and Ola and Oboh (2000).

Data analysis of proximate composition, minerals and anti-nutritional factors were estimated in triplicates and the means were separated and compared across the Grewia species using multivariate analysis in IBM SPSS Statistics ver. 15 developed by Norman H. Nie, St Louis, Missouri, USA.

\section{Results and discussion}

The evaluation of nutrient composition involved the evaluation of moisture content, crude fibres, ash, crude proteins, lipids and carbohydrates of edible mushroom varieties that are shown in Table 1. Notably, there was a significant difference $(\mathrm{p}<0.05)$ in proximate parameters in G. forbesii and G. bicolor. The values of moisture content reported in this study corroborate with the values of $13-15 \%$ in other Grewia species reported by Elhassan and Yapi (2010). However, Murray et al. (2001) recorded higher moisture content of $26 \%$ for Grewia bicolor fruits. According to Tairo et al.
(2011), the low moisture content suggests that the fruits had higher dry matter yields as that can be a sign of their long shelf life. Crude fibre content was slightly higher in G. bicolor with $33.15 \%$ compared with $31.95 \%$ in $G$. forbesii. The values obtained in this study were in line with the values of $20-42 \%$ crude fibre reported by Elhassan and Yapi (2010). On the other hand, Yadav (1999) reported low fibre content amounting to $5.3 \%$ in G. asiatica.

The ash content was higher in G. bicolor $(4.3 \%)$ than that of $3.86 \%$ in G. forbesii. The results are comparable to the values of 3.4$5.2 \%$ reported by Elhassan and Yapi (2010). Pundlik (2020) reported high values of 5-13\% ash content for some species in the Grewia genus. The range of ash content reported in this study signifies that ash is essential to a food's nourishment and longevity (Tairo 2011). G. forbesii had slightly higher protein content (7.44\%) compared to that of $7 \%$ in G. bicolor. Murray et al. (2001) recorded a protein content of $7.1 \%$ in G. villosa. Lipid contents of $1.28 \%$ and $1.37 \%$ were recorded for $G$. forbesii and $G$. bicolor, respectively. The results are in line with the earlier study by Pundlik (2020) that recorded more than 3\% lipid content for other species in the genus Grewia. The lipid contents reported in this study are essential because they provide the body with maximum energy (Tairo 2011). Also the low level of lipid content implies that they play crucial roles as enzyme cofactors and hydrophobic anchors for proteins (Fahy et al. 2005).

Table 1: Proximate composition of Grewia forbesii Hav. ex Mast and Grewia bicolor Juss from Kitapilimwa Forest Reserve

\begin{tabular}{lll}
\hline Parameters (\%) & Grewia species* & \\
\cline { 2 - 3 } & Grewia forbesii & Grewia bicolor \\
\hline Moisture content & $14.14 \pm 0.65$ & $13.98 \pm 0.64$ \\
Crude fibres & $31.95 \pm 4.82$ & $33.15 \pm 4.83$ \\
Ash content & $3.86 \pm 0.54$ & $4.3 \pm 0.83$ \\
Protein content & $7.44 \pm 0.53$ & $7.00 \pm 0.62$ \\
Lipids & $1.28 \pm 0.18$ & $1.37 \pm 0.16$ \\
Carbohydrates & $68.90 \pm 5.34$ & $70.00 \pm 4.95$ \\
\hline
\end{tabular}

\footnotetext{
*Mean values \pm standard deviation of the triplicate; expressed in $\%$.
} 
The carbohydrate content was higher in $G$. bicolor $(70 \%)$ than in G. forbesii $(68.9 \%)$. These results are comparable to the values of $61.21 \%$ and $77 \%$ reported by Tairo (2011) for fruits producing plants such as Vangueria infausta and Vitex mombassae, respectively. Pundlik (2020) reported low values of $20-45 \%$ carbohydrates contents for species of the genus Grewia. The higher values reported in this study suggest that Grewia fruits have high calorific value and can be considered as one of the high energy-rich foods.

\section{Mineral content composition}

The mineral nutrients composition of $G$. forbesii and G. bicolor are given in Table 2 . The results revealed that there was a significant difference $(\mathrm{p}<0.05)$ in the mineral nutrients in $G$. forbesii and G. bicolor. As shown in the table, G. forbesii has low calcium content (453 $\mathrm{mg} / 100 \mathrm{~g}$ ) compared with $582 \mathrm{mg} / 100 \mathrm{~g}$ in $G$. bicolor. The level of calcium content is higher than the range of $179-180 \mathrm{mg} / 100 \mathrm{~g}$ reported by Feyssa et al. (2011) in G. flavescens. These results support the fact the selected species have nutritional potentetials than other species in the genus. G. forbesii has high manganese, copper and zinc content compared with $G$. bicolor. Earlier study by Elhassan and Yapi (2010) showed low concentrations (less than $2.5 \mathrm{mg} / 100 \mathrm{~g}$ ) of manganese, copper and zinc in most of the studied species. The recent study showed that iron concentration was high in $G$. forbesii $(24.45 \%)$ than in G. bicolor $(20.73$ $\mathrm{mg} / 100 \mathrm{~g})$. These values showed extremely high iron content in the studies species. Presence of high amounts of iron implies that Grewia fruits favour iron absorption when consumed. Traditionally use of Grewia fruits can support to treat anaemia. Previous study by Elhassan and Yapi (2010) showed that the plant species iron content ranged from the lowest $20.8 \mathrm{mg} / 100 \mathrm{~g}$ to the highest 29.6 $\mathrm{mg} / 100 \mathrm{~g}$.

The results from analysis revealed that there was no significant difference in levels of anti-nutrients in both $G$. forbesii and $G$. bicolor. The levels of anti-nutrients are shown in Table 3. Tannin content was slightly low $(1.64 \%)$ in $G$. forbsii than in G. bicolor $(1.69 \%)$. The results are in line with the findings of a previous study by Chung et al. (1998) that reported tannin content of species form the genus Grewia ranging from $1.13 \%$ to $2.46 \%$. Phylates were almost the same $(0.13 \%)$. The levels of phylates were within the range of $0.08 \%$ to $0.17 \%$ as reported by Sati and Ahmed (2018). The low levels of anti-nutrients suggest that Grewia fruits can contribute to the human nutrient requirements.

Table 2: Mineral nutrient content of Grewia forbesii Hav. ex Mast and Grewia bicolor Juss from Kitapilimwa Forest Reserve

\begin{tabular}{lll}
\hline Parameters (mg/100 g) & \multicolumn{2}{c}{ Grewia species* } \\
\cline { 2 - 3 } & Grewia forbesii & Grewia bicolor \\
\hline $\mathrm{Ca}$ & $453.00 \pm 17.80$ & $582.00 \pm 17.80$ \\
$\mathrm{~K}$ & $898 \pm 8.49$ & $879.00 \pm 8.49$ \\
$\mathrm{Mn}$ & $3.60 \pm 0.17$ & $3.20 \pm 0.16$ \\
$\mathrm{Fe}$ & $24.45 \pm 0.53$ & $20.73 \pm 0.53$ \\
$\mathrm{Cu}$ & $1.32 \pm 0.17$ & $1.23 \pm 0.17$ \\
$\mathrm{Zn}$ & $0.68 \pm 0.25$ & $1.59 \pm 0.34$ \\
\hline
\end{tabular}

*Mean values \pm standard deviation of the triplicate. 
Table 3: Some anti-nutritional contents of Grewia forbesii Hav. ex Mast and Grewia bicolor Juss from Kitapilimwa Forest Reserve

\begin{tabular}{llc}
\hline Parameters (\%) & \multicolumn{2}{c}{ Grewia species* } \\
\cline { 2 - 3 } & Grewia forbesii & Grewia bicolor \\
\hline Tannins & $1.64 \pm 0.31$ & $1.69 \pm 0.22$ \\
Phylates & $0.13 \pm 0.11$ & $0.13 \pm 0.12$ \\
\hline
\end{tabular}

*Mean values \pm standard deviation of the duplicate.

\section{Conclusion and recommendations}

Based on the results, fruits of the studied Grewia spp locally consumed by the majority of the people living in Iringa District contain enough essential nutrients like carbohydrates, lipids, proteins and mineral nutrients such as calcium, potassium, manganese, copper and zinc that can serve as potential sources of food. The levels of anti-nutrients (tannins and phylates) are below the threshold levels. It can therefore, be concluded that the Grewia fruits can contribute to the human nutrient requirements and could be used as sources of nutrients supplements. Further research is needed to explore more on the bioactive compounds in Grewia species.

\section{Acknowledgments}

The author would like to thank Iringa District Forest Officer and Village Leader for providing opportunity and support to conduct this study in the area. Also, the author thanks all who participated in data collection and analysis.

\section{References}

AOAC 2000 Official Methods of Analysis. 17 $7^{\text {th }}$

Edition, The Association of Official Analytical Chemists, Gaithersburg, MD, USA.

Elhassan GOM and Yagi SM 2010 Nutritional Composition of Grewia Species (Grewia tenax (Forsk.) Fiori, G. flavescens Juss and G. villosa Willd) Fruits. Adv. J. Food Sci. Technol. 2(3): 159-162.

Fahy E, Subramaniam S, Brown H A, Glass CK, Merrill AH, Murphy RC, Raetz CR, Russell DW, Seyama Y, Shaw W and Shimizu T 2005 A comprehensive classification system for lipids. J. Lipid Sci. Technol. 46(5): 839-861.
Feyssa DH, Njoka JT, Asfaw Z and Nyangito MM 2011 Wild edible fruits of importance for human nutrition in semi-arid parts of East Shewa Zone, Ethiopia: Associated indigenous knowledge and implications to food security. Pakistan J. Nutr. 10(1): 4050.

Food and Agriculture Organization (FAO) 2000 An information bulletin on non-Wood forest products: Non-wood news, No. 7.

FAO 2010 Global Forest Resources Assessment Key Findings. Food and Agriculture Organization of the United Nations. http:www.fao.org./forestry/fra/en.

Heuzé V, Tran G, Delagarde R, Bastianelli D, Lebas F 2015 False brandy bush (Grewia bicolor). Feedipedia, a programme by INRAE, CIRAD, AFZ and FAO. https://www.feedipedia.org/ node/148 Last updated on July 3, 2015, 11:20

Murray SS, Schoeninger MJ, Bunn HT, Pickering TR and Marlett JA 2001 Nutritional composition of some wild plant foods and honey used by Hadza foragers of Tanzania. J. Food Compos. Anal. 14(1): 313.

Njau P 2005 Contritibution of Non-Wood Forest Products (NWFP) to the livelihood of the communities surrounding Nyang'oro Forest RESERVE in Iringa District. Special Project. Pp 58.

Ola FL and Oboh G 2000 Food value of two Nigerian edible mushrooms (Termitomycetes stratus and Termitomycetes robustus). J. Technosci. 4: $1-3$.

Pundlik SPP 2020 The study on proximate composition of different species of Genus Grewia from western Maharashtra. Eur. J. Mol. Clin. Med. 7(10): 3919-3924. 
Ruffo CK, Birnie A, Tengnäs B 2002 Edible wild plants of Tanzania. Regional Land Management Unit/Sida (RELMA), Technical Handbook Series 27. Nairobi, Kenya.

Sati NME and Ahmed FAM 2018 Botanical overview and chemical composition of some Grewia spp"Gudeim plant" in Sudan. Open Sci. J. 3(1).

Singleton VL, Orthofer R, and LamuelaRaventós RM 1999 Analysis of total phenols and other oxidation substrates and antioxidants by means of folin-ciocalteau reagent. Method Enzymol. 299: 152-178.

Tairo VE, Jesse TN, Lukhoba WC and Lyaruu HVM 2011 Nutritive and anti-nutritive qualities of most preferred edible woody plants in selected drylands of Iringa District, Tanzania. Pakistan J. Nutr. 10 (8): 786-791.

Tairo VE 2011 Utilization of woody plants during times of food scarcity from selected drylands of Iringa district, Tanzania. $\mathrm{PhD}$ Thesis, University of Nairobi.

URT (United Republic of Tanzania) 2001 Forest Policy. Ministry of Natural Resources and Tourism, Forestry and Beekeeping Division, Dar-es-Salaam, Tanzania.

Yadav AK 1999 Phalsa: A Potential New Small Fruit for Georgia. In: Janick J (Ed), Perspectives on New Crops and New Uses. ASHS Press, pp: 348-352. 